\title{
Strategi Digital Public Relations Pegiat Podcast dalam Membangun Brand Engagement (Studi Kasus dalam Podcast Duo Budjang)
}

\author{
Bella Chitra, Roswita Oktavianti \\ Bella.915160124@stu.untar.ac.id,roswitao@fikom.untar.ac.id \\ Fakultas Ilmu Komunikasi Universitas Tarumanagara
}

\begin{abstract}
This research studies about the digital public relations strategy of podcast enthusiasts in developing their brand engagement. The researcher used concepts of digital public relations and brand engagement in explaining the analysis. The scope of digital public relations concepts cover online or website publicity, social media, and online communities. Meanwhile, the concept of brand engagement can be seen in active interactions with followers or listeners. This research is a qualitative research using the case study methodology. The case studies used the Duo Budjang podcast. This study finds that the promotion on social media is more effective and efficient than on websites, especially on Instagram because the majority of the users are millennials. The promotion will be successful if the selection of media channels is tailored according to the target audience and consistent in its management. In developing the engagement, podcast enthusiasts pay attention to and make active interactions on both online and offline. One success story of the engagement is the existence an online or virtual community established by the loyal listeners of the podcasts. The community also helps in promoting the podcasts.
\end{abstract}

Keywords: brand engagement, digital public relations, podcast

\begin{abstract}
Abstrak
Penelitian ini mengangkat tentang strategi digital public relations pegiat podcast dalam membangun brand engagement. Konsep yang digunakan yaitu digital public relations dan brand engagement. Konsep digital public relations seperti publisitas online atau website, media sosial, dan komunitas online. Sedangkan konsep brand engagement dapat dilihat pada interaksi yang aktif terhadap followers atau pendengarnya. Penelitian ini merupakan penelitian kualitatif menggunakan metode studi kasus. Studi kasus dilakukan terhadap podcast Duo Budjang. Hasil penelitian ini adalah promosi di media sosial lebih efektif dan efisien daripada di website, khususnya di Instagram karena mayoritas pengguna adalah generasi milenial. Promosi akan berhasil jika pemilihan saluran media sesuai target audience dan konsisten dalam pengelolaannya. Dalam membangun engagement, pegiat podcast memperhatikan dan membuat interaksi yang aktif baik di dalam jaringan (daring) maupun di luar jaringan (luring). Salah satu contoh keberhasilan dari engagement yang dibangun adalah adanya komunitas online atau virtual yang merupakan pendengar setia podcast. Komunitas juga membantu dalam mempromosikan podcast.
\end{abstract}

Kata Kunci: Brand Engagement, digital public relations, podcast 


\section{Pendahuluan}

Menurut Rogers dan Kincaid, komunikasi merupakan proses yang dilakukan individu-individu dengan melakukan pertukaran informasi dan membentuk informasi tersebut sehingga akan tercipta suatu rasa saling pengertian yang mendalam (Cangara, 2016). Dengan adanya perkembangan teknologi informasi yaitu internet, maka memudahkan masyarakat untuk berkomunikasi maupun berinteraksi tanpa ada batasan ruang dan waktu. Hal ini juga mempengaruhi kegiatan public relations. Public relations sebagai ujung tombak dalam membangun citra atau brand image mempunyai peran penting dalam meningkatkan kepercayaan publik. Public relations menjadi bagian penting dari usaha pemasaran perusahaan untuk mengembangkan usahanya dan mencapai tujuannya (Kartikasari, 2017).

Jika sebelumnya kegiatan public relations menggunakan informasi pada media-media konvensional seperti televisi dan surat kabar, maka di tengah gempuran inovasi internet yang terus berkembang pesat dan bervariasi, kegiatan public relations beralih kepada jalur digital yang disebut sebagai cyber public relations (Aprinta, 2014). Cyber public relations merupakan kegiatan yang digunakan oleh banyak perusahaan maupun organisasi untuk membangun brand engagement. Brand engagement merupakan konsumen yang memiliki hubungan dengan merek suatu produk dan mempengaruhi konsumen tersebut dalam kognitif, emosional dan perilaku terhadap merek (Hollebeek \& Chen, 2014). Walaupun fokus utama kegiatan cyber public relations adalah pasar online, tetapi akan lebih maksimal apabila digabungkan dengan kegiatan public relations secara offline.

Salah satu konten digital yang sedang berkembang pesat saat ini adalah podcast. Podcast diartikan materi audio atau video yang tersedia di internet yang dapat secara otomatis dipindahkan ke komputer atau media pemutar portable baik secara gratis maupun berlangganan (Fadilah, Yudhapramesti \& Aristi, 2017). Menurut survei yang dilakukan oleh DailySocial dan JakPat Mobile Survey Platform, bahwa 65,00\% masyarakat tertarik terhadap konten podcast dan 62,69\% karena adanya fleksibilitas akses (Eka, 2018). Adanya audio/suara, maka dapat lebih interaktif dan lebih memungkinkan terjadinya interaksi dua arah serta dapat didengarkan dimana saja dan dalam kondisi apapun. Masyarakat saat ini dapat membuat podcast karena media ini merupakan wadah orang-orang berpendapat ataupun informasi yang mereka miliki.

Pegiat podcast yang populer di Indonesia saat ini yaitu "Duo Budjang" membahas topik keseharian, budaya pop, sampai isu-isu sosial. Duo Budjang terdiri dari Mario Pratama yang biasa dipanggil Mario dan Narendra Pawaka yang biasa dipanggil Eda, yang juga merupakan penyiar radio Prambors dan talent di Narasi.tv. Narasi.tv merupakan perusahaan startup dalam bidang TV digital. Duo Budjang ini berawal melakukan podcast audio di layanan streaming musik seperti soundcloud dan spotify. Saat ini Duo Budjang memasukkan podcast-nya di spotify dan youtube channel Narasi.tv. Podcast Duo Budjang ini muncul pada tahun 2017, dan perkembangannya terus meningkat sehingga Duo Budjang juga memiliki konten podcast di kanal Narasi TV.

Dalam penelitian ini, maka masalah tersebut dapat dirumuskan yaitu bagaimana strategi digital public relations pegiat podcast dalam membangun brand engagement. Penelitian ini bertujuan untuk memahami secara dalam mengenai strategi digital public relations yang dilakukan Duo Budjang untuk membangun brand engagement. 


\section{Metode Penelitian}

Penelitian ini menggunakan pendekatan kualitatif. Penelitian kualitatif adalah suatu penelitian yang memiliki tujuan untuk memahami fenomena dalam lingkup sosial secara alamiah dengan melakukan proses interaksi komunikasi yang mendalam antara peneliti dan fenomena yang diteliti (Herdiansyah, 2011).

Selain itu, penulis melakukan penelitian dengan metode studi kasus. Penelitian studi kasus adalah suatu penelitian kualitatif dengan menemukan makna, menyelidiki proses, dan memperoleh pemahaman yang mendalam dari suatu yang sedang diteliti (Emzir, 2012). Dalam penelitian ini, studi kasus digunakan terhadap podcast Duo Budjang untuk menggali dan mengetahui secara mendalam bagaimana strategi yang digunakan untuk membangun brand engagement. Penulis menggunakan metode pengumpulan data dengan wawancara mendalam dan observasi.

Dalam penelitian ini yang menjadi subjek penelitian yaitu Duo Budjang (Mario Pratama dan Narendra Pawaka), yang sekaligus merupakan orang yang membuat, menentukan dan menjalankan strategi digital public relations tersebut. Objek dari penelitian ini adalah strategi digital public relations pegiat podcast tersebut.

Triangulasi data yaitu proses untuk memantapkan kepercayaan (kredibilitas/validitas) dan konsistensi (realibitas) data, dan bermanfaat untuk membantu analisis data di lapangan (Gunawan, 2014). Narasumber triangulasinya adalah salah satu orang yang bekerja di PR agensi yaitu Maverick Indonesia yang bernama Karen Kusnadi yang menjabat sebagai manajer spesialis menangani media.

\section{Hasil Penemuan dan Diskusi}

Penulis melakukan wawancara langsung dan observasi di kantor Narasi TV di studio Duo Budjang pada hari Jumat, 1 November 2019.

Menurut Mario, terdapat sebuah artikel dari Gary Vaynerchuk yang merupakan seorang podcaster dan entrepreneur, bahwa konsumsi audio di Amerika Serikat tahun 2016 meningkat sekitar 40-50\%. Artikel ini membuat Duo Budjang tertarik untuk membuat podcast karena mereka memiliki latar belakang siaran radio. Pada dasarnya, siaran radio memiliki batasan waktu untuk berbicara, sehingga mereka merasa kurang maksimal untuk menyampaikan pesan atau cerita.

"kalau aku pada saat itu ngelihat sebuah artikel dari Gary Vaynerchuk, itu juga seorang podcaster dan entrepreneur juga, dia bilang konsumsi audio di Amerika Serikat tahun 2016 itu naik gede banget 40-50\%, jadi memang kalau di Amerika sendiri podcast mungkin sudah seperti sekarang ya pada tahun itu, aku tertarik karena bener kata Eda, aku lagi bosan-bosannya dan aku pas saat itu masih belum menemukan alasan kenapa aku harus nge-youtube karena pada saat itu alternatifnya adalah kalau mau bikin konten di youtube gitu jadi youtuber, cuman aku belum menemukan apa alasan aku harus nge-youtube, hidup aku gak terlalu menarik, aku juga gak punya alat-alatnya dan podcast tuh paling gampang. Apalagi aku sama Eda background-nya kan siaran dan kalau siaran itu cuman 3 menit kalau ngomong, kalau lebih dari itu kadang suka dimarahin, nah aku ngerasa susah nih untuk menyampaikan sebuah pesan atau cerita, akhirnya bikin podcast deh, durasinya saat itu aku udah tau 1 jam." (Mario Pratama, Pegiat Podcast Duo Budjang, 2019) 
Salah satu strategi yang dilakukan Duo Budjang adalah konsisten. Duo Budjang selalu konsisten dalam mengunggah konten podcast di spotify maupun soundcloud. Seperti yang dikatakan Eda, Duo Budjang memiliki motto yang terinspirasi dari podcast "Awal Minggu" yang dimiliki oleh Adriano Qalbi, dimana podcast tersebut diunggah setiap hari Senin. Maka dari itu, Duo Budjang konsisten untuk mengunggah podcast-nya setiap hari Rabu. Motto ini membuat Duo Budjang untuk lebih disiplin sehingga manfaat podcast dapat dirasakan untuk diri sendiri juga.

Menurut Mario, ciri khas podcast yaitu bercerita. Bercerita dianggap sebagai sesi terapi seperti halnya menulis diary. Duo Budjang yang terdiri dari dua orang penyiar radio ini juga memiliki tujuan dalam membuat podcast yaitu untuk melatih chemistry mereka. Konsisten merupakan kunci kesuksesan dalam melakukan sesuatu. Dalam hal ini, pendengar dapat mengetahui jadwal podcast yang baru sehingga mereka akan selalu menjadi pendengar setianya.

Duo Budjang seharusnya menentukan target audience terlebih dahulu. Setelah itu, baru membuat jenis konten yang sesuai dengan target audience. Dalam penelitian ini, pegiat podcast memiliki target audience yaitu generasi milenial. Maka jenis konten yang disajikan yaitu bersifat ringan, menggunakan bahasa milenial tetapi juga informatif dan bermakna agar lebih mudah diserap oleh pendengar.

Sebelum melakukan perencanaan strategi, pegiat podcast Duo Budjang juga menganalisis situasi podcast menggunakan kekuatan (strengths), kelemahan (weaknesses), peluang (opportunities), dan ancaman (threats). Pegiat podcast percaya bahwa podcast berhubungan erat dengan audio. Audio tidak akan punah tetapi akan terus berkembang perangkat audionya. Hal ini dapat dilihat dengan berkembangnya audio maka muncullah podcast. Beberapa radio sekarang ini juga sudah memiliki jaringan podcast sendiri. Kelebihan audio daripada visual yaitu pendengar yang sedang mendengarkan audio tidak terpaku dengan satu kegiatan saja, melainkan bisa dengan mengerjakan pekerjaan yang lain. Kelebihan podcast dibandingkan dengan radio adalah podcast tidak terbatas durasi sehingga cerita lebih menarik, sementara itu radio memiliki durasi berbicara yang terbatas. Dengan mudahnya membuat podcast sehingga bermunculan banyak konten kreator.

Lawannya audio adalah visual. Hal ini merupakan suatu kelemahan serta ancaman bagi podcast. Seperti yang dikatakan Karen Kusnadi sebagai manajer spesialis media Maverick Indonesia (2019), banyak orang yang juga menyukai visual yang menarik. Maraknya inovasi yang terus bertambah dan berkembang, menyebabkan munculnya konten multimedia yang beragam.

Kalau weaknesses, kurangnya visual karena podcast hanya audio kan, sementara banyak orang juga menggemari visual yang menarik. Opportunities yaitu bisa menghasilkan lebih banyak content creator karena banyak orang tidak suka tampil, lebih suka berada di balik layar. Dan threats podcast yaitu maraknya inovasi format dan konten multimedia seperti gambar bergerak/gif, video interaktif." (Karen Kusnadi, Manajer Spesialis Media Maverick Indonesia, 2019).

Menurut Aprinta (2014), strategi cyber public relations yang dapat digunakan antara lain:

1. Publikasi Online

Mempromosikan sesuatu hal dengan mempublikasikannya secara online sehingga masyarakat bisa menjangkaunya. Publisitas merupakan kegiatan yang sama halnya dengan mengiklan tetapi publisitas biasanya tanpa biaya (Ristania \& Justianto, 2013). 
Duo Budjang tidak melakukan promosi di website karena adanya keterbatasan sumber daya manusia yang dimiliki sehingga jika memiliki website tetapi tidak terkelola dengan baik, maka menjadi timbal balik yang negatif terhadap pegiat podcast-nya itu sendiri.

Website merupakan salah satu identitas yang penting bagi perusahaanperusahaan. Hal ini untuk menunjukkan keseriusan suatu perusahaan dalam mempromosikan produk maupun perusahaanya sendiri. Dalam mempromosikan sesuatu, harus mengidentifikasi terlebih dahulu terhadap sarana promosi yang digunakan. Tujuan dari identifikasi ini yaitu agar promosi langsung sampai ke target audience. Website bukan merupakan sarana promosi yang tepat untuk generasi milenial, karena mereka mayoritas menggunakan media sosial.

2. Media Sosial

Duo Budjang menggunakan salah satu media sosial yaitu Instagram untuk mempromosikan podcast. Ini merupakan langkah yang tepat dalam melakukan promosi, karena generasi milenial mayoritas menggunakan Instagram. Salah satu portal diskon tanah air yaitu CupoNation, melakukan studi tentang pengguna media sosial dan aplikasi yang banyak digunakan di Indonesia tahun 2019 yang dilansir oleh Liputan 6, bahwa pengguna Instagram di Indonesia mencapai peringkat keempat dengan rentang usia 18-24 tahun.

Karakteristik dari media sosial yaitu terbentuknya jaringan antarpengguna. Dalam jaringan tersebut, tidak hanya memperluas hubungan tetapi juga membangun dan berinteraksi antarpengguna (Nasrullah, 2017). Pada penelitian ini, pegiat podcast juga sangat aktif dalam mempromosikan podcast dan berinteraksi dengan followers-nya di Instagram dengan cara membalas pesan atau komentar serta memperhatikan likes. Pegiat podcast juga pernah membuat konten podcast berdasarkan permintaan pendengarnya. Dengan cara tersebut, dapat meningkatnya engagement pendengar karena pendengar merasa dekat dengan pegiat podcast.

3. Komunitas Online / Komunitas Virtual

Duo Budjang juga memiliki komunitas virtual yang juga sangat membantu dalam mempromosikan podcast. Sama halnya menurut Aprinta (2014), komunitas online dapat membentuk citra yang positif. Adanya interaksi yang aktif secara online maupun offline, maka secara tidak langsung dapat membentuk komunitas yang memiliki kepentingan yang sama yaitu menjadi pendengar setia sekaligus membantu menyebarkan atau mempromosikannya.

Dalam penelitian ini, Duo Budjang telah membentuk engagement dengan baik seperti selalu memperhatikan dan membalas likes maupun komentar di Instagram-nya. Hal tersebut merupakan salah satu interaksi yang dilakukan pegiat podcast terhadap followers atau pendengarnya. Pegiat podcast selalu memiliki jadwal untuk mengunggah di Instagram agar terus menimbulkan interaksi yang aktif. Pegiat podcast tidak hanya pernah membuat podcast bersama komunitasnya tetapi juga sudah beberapa kali berbincang-bincang dengan sejumlah nama-nama yang populer. Hal ini sudah baik strategi yang digunakan, karena konten tidak monoton dengan mengundang bintang tamu seperti Roy Ricardo, Local Heroes, Denny Ertanto, dan lain-lain sehingga terbentuknya perbincangan dari masing-masing pendapat yang berbeda. Dengan mengundang bintang tamu yang populer juga merupakan adanya co-branding 
yang juga dapat membantu mempromosikan kepada masyarakat baru agar mengenal dan mendengarkan podcast-nya.

Menurut Kotler \& Amstrong, co-branding yaitu strategi dengan menggunakan nama merek dari dua perusahaan yang berbeda pada produk yang sama (Nurpriyanti \& Hurriyati, 2016).

Pegiat podcast sudah menentukan media sosial yang digunakan untuk mempromosikan podcast-nya sehingga mereka telah membangun interaksi dengan maksimal sehingga hubungan dengan followers-nya sudah sangat kuat. Menurut Pandrianto dan Sukendro (2018), dalam membangun brand engagement harus ada daya tarik dengan mendefinisikan serta merumuskan kembali apa tujuan dalam mendistribusikan konten digital melalui media sosial tersebut.

\section{Kesimpulan}

Dalam penelitian ini, target audience-nya yaitu generasi milenial, maka promosi di media sosial lebih efektif dan efisien daripada di website, khususnya Instagram karena mayoritas pengguna Instagram adalah generasi milenial. Promosi di berbagai saluran media bukan pilihan yang tepat jika tidak terkelola dengan baik, lebih baik fokus di beberapa saluran media saja yang sesuai dengan target audience dan konsisten untuk dikelola dengan baik.

Dalam membangun engagement, pegiat podcast memperhatikan dan membuat interaksi yang aktif dengan followers-nya baik secara dalam jaringan (daring) maupun luar jaringan (luring). Pegiat podcast juga selalu konsisten dalam mengunggah podcast-nya dan promosi di Instagram. Dalam konten podcast, pegiat podcast juga sudah beberapa kali berbincang-bincang dengan bintang tamu populer yang juga dapat berpengaruh dalam meningkatkan engagement.

\section{Ucapan Terima Kasih}

Ucapan terima kasih diberikan kepada Fakultas Ilmu Komunikasi Universitas Tarumanagara, dan juga kepada narasumber yang telah membantu sebagai narasumber, keluarga serta Kevin Sanjaya, Eunike Pribadi, Jesica Sharon yang selalu memberikan dukungan kepada penulis, dan kepada semua pihak yang telah mendukung dan membantu penelitian ini.

\section{Daftar Pustaka}

Aprinta, Gita. (2014). Strategi Cyber Public Relations dalam Pembentukan Citra Institusi Pendidikan Tinggi Swasta. Jurnal The Messenger, 6 (1), 1-6. Agustus 19, 2019. Terarsip di: http://journals.usm.ac.id/index.php/themessenger/article/view/161/133

Cangara, Haffied. (2016). Pengantar Ilmu Komunikasi (ed 2). Jakarta: PT. Rajagrafindo Persada.

Eka, Randi. (2018, Agustus 27). Laporan DailySocial: Penggunaan Layanan Podcast 2018. Januari 7, 2020. DailySocial database. https://dailysocial.id/post/laporan-dailysocial-penggunaan-layanan-podcast2018

Emzir. (2012). Analisis Data: Metodologi Penelitian Kualitatif. Rajawali Pers. 
Fadilah, Efi., Yudhapramesti, Pandan. \& Aristi, Nindi. (2017). Podcast Sebagai Alternatif Distribusi Konten Audio. Kajian Jurnalisme Universitas Padjadjaran, 1 (1), 3,10, Agustus 19, 2019. Terarsip di: http://jurnal.unpad.ac.id/kajian-jurnalisme/article/view/10562/6395

Gunawan, Imam. (2014). Metode Penelitian Kualitatif: Teori dan Praktik (ed. 1). Jakarta: Bumi Aksara.

Herdiansyah, Haris. (2011). Metodologi Penelitian Kualitatif untuk Ilmu-Ilmu Sosial. Jakarta: Salemba Humanika.

Hollebeek, Linda D. \& Chen, Tom. (2014). Exploring Positively - Versus Negatively -Valenced Brand Engagement: a conceptual model. Journal of Product \& Brand Management, 23 (1), Agustus 23, 2019. Terarsip di: https://www.emerald.com/insight/content/doi/10.1108/JPBM-06-20130332/full/html

Kartikasari, Nita. (2017). Viral: Gebrakan Kekinian Public Relations di Era Digital. E-book, xi-xii. Agustus 19, 2019. Terarsip di: https://books.google.co.id/books?hl=en\&lr=\&id=xstGDwAAQBAJ\&oi=fnd $\& p g=P P 1 \& d q=$ persepsi + digital + public $+\& o t s=r Y j i N Y K G 9 J \& s i g=3 F U z 6 q C F$ -YU58F4bWdbzBJ1A9Bg\&redir_esc $=\mathrm{y} \# \mathrm{v}=$ onepage \&q \&f=false

Nasrullah, Rulli. (2017). Media Sosial (Perspektif Komunikasi, Budaya, dan Sosioteknologi. Bandung: PT Remaja Rosdakarya.

Nurpriyanti, Vika. \& Hurriyati, Ratih. (2016). Pengaruh Kinerja Co-Branding Terhadap Keputusan Pembelian (Survei pada Mini Market Penjual Es Krim Wall's Selection Oreo di Kecamatan Cikajang-Garut). Journal of Business Management and Entrepreneurship Education, 1 (1), 6, Januari 9, 2020. Terarsip di: https://ejournal.upi.edu/index.php/JBME/article/viewFile/2281/1581

Pandrianto, Nigar. \& Sukendro, Gregorius Genep. (2018). Analisis Strategi Pesan Content Marketing untuk Mempertahankan Brand Engagement. Jurnal Komunikasi Fakultas Ilmu Komunikasi Universitas Tarumanagara, Agustus 25, $2019 . \quad$ Terarsip di: https://www.journal.untar.ac.id/index.php/komunikasi/article/view/2619

Ristania, Novia. \& Justianto, Jerry S. (2013). Analisa Pengaruh Harga, Promosi dan Viral Marketing Terhadap Keputusan Pembelian pada "Online Shop" SNexian Melalui Facebook. Jurnal Binus, 5 (2), 7, Agustus 23, 2019. Terarsip di: https://journal.binus.ac.id/index.php/JBSE/article/view/772/743 